Fecha de recepción: marzo 2020 Fecha de aceptación: abril 2020 Versión final: junio 2020

\section{The Black Heroine in the Mirror: crossing the threshold of the specular image, the esoteric journey and the encounter with the annihilating $I$ in Jordan Peele's Us}

Gitanjali Kapila $^{(1)}$

\begin{abstract}
Using the conceptual framework of the mirror-stage established by Lacan to describe the initial anchoring of the subject, this paper seeks to interrogate the mirror as the locus of a secondary elaboration of the hero's journey which follows its traditional articulation adumbrated by Joseph Campbell in The Hero with a Thousand Faces. If the goal of the classic hero as Campbell suggests is to exit the nursery which represents the subject's entrapment in Oedipal triangulation, this study posits that the successful selfrelease of the hero from the nursery simply sees him entering another nursery where the hero's world is conceived of as a series of infinitely nested nurseries without exit. The mirror and its binding capture become the exemplary point of departure for the secondary elaboration of the journey for which, it turns out, the black heroine is the ideal adventurer. It is no wonder then that Jordan Peele's Us is replete with mirrors functioning as cinematic signifiers for the portals effecting the subject's displacement not towards an outer world of aggressive fathers and unobtainable ideal mothers; but, rather into a proximate encounter with the self, one precipitated by the mirror where the goal of the journey -the one that can only be revealed by the black heroine- is the apprehension of the "cipher of [her] moral destiny" and the unfathomable cartography of her true exit.
\end{abstract}

Keywords: Us - Snow White - Peele - Lacan - Campbell - Freud - I Function - mirror stage - psychoanalysis - hero -hero's journey - race.

[Abstracts in spanish and portuguese on the pages 230-231]

${ }^{(1)}$ Gitanjali Kapila is an Adjunct Lecturer at Columbia College Chicago in Cinema and Television Arts and an Adjunct Assistant Professor at the School of the Art Institute in Film, Video, New Media and Animation. She received an MFA in Filmmaking from Columbia University in the City of New York. She teaches foundational courses in film production as well as beginning and advanced courses in screenwriting and worldbuilding. Her short film Breathing above the Treeline recently completed its festival run with 14 screenings world-wide including in Europe, India, China and the US. She is currently in post-production on a new dramatic short, Bat, for which she received an 
Illinois Arts Council Grant and a grant from the School of the Art Institute. She also recently presented on writing for viewer interactive episodic narrative at the CILECT Congress 2019 held in Moscow in October 2019.

In Jordan Peele's masterwork Us the first words uttered by Red to Addy in the living room of Addy and Gabe's summer home are "once upon a time there was a girl" (00:45:05) which situates the viewer squarely within the narrative framework of a fairytale, specifically Disney's 1937 animation of Snow White which begins with an image of a book opening to a page on which "Once upon a time there lived a lovely little Princess named Snow White" (00:01:36) is written. Peele establishes Snow White as Addy's fairytale antecedent in the first scene where Addy walks on the Santa Cruz boardwalk with her parents carrying a candied apple, an indisputable reference to the apple given to Snow White by the Evil Queen masquerading as a hag. As already discussed in my previous paper on the subject ${ }^{1}$, fairytale structure constitutes a partial and/or nested expression(s) of the hero's journey as described by Joseph Campbell in The Hero with a Thousand Faces. On the boardwalk Addy lags behind her bickering mother and father so they migrate in a triangular formation through the arcade which is suggestive of the hero's subject position prior to his departure on the journey. Referencing Freud, Campbell characterizes the uninitiated subject as someone who "instead of maturing remain[s] locked in the romance of the nursery" (Campbell 5) and whose "first and only emotional involvement" (Campbell 3 ) is "that of the tragicomic triangle of the nursery" (Campbell 3) where the nursery functions a metonym for Oedipal entrapment. Later in the chapter entitled The World Navel Campbell defines the goal of the hero in undertaking the journey as "the unlocking and release again of the flow of life into the body of the world" (Campbell 32) though how this poetically-expressed outcome resolves with Campbell's psychoanalytic framing of the hero's "inhibition in development" (Campbell 4) is not clear. An alternative articulation of the successful resolution of the hero-task which is consistent with Campbell's invocation of Freud's model is thus required: the hero who seeks to divest himself of his inappropriate Oedipal longings accomplishes this goal when he, in fact, exits the nursery. It is important to note here that the hero does not exit the nursery in order to embark on the journey; rather, the hero embarks on the journey and submits to the trial(s) of the hero-path in order to unlock the nursery door at the conclusion of his journey. Rather than remaining within the ambit of the Oedipal corral erected by her unwitting parents, Addy wanders away from $i^{2}$ and heads towards a staircase where an Exit sign marks the threshold between the boardwalk and the beach. Still holding the apple Addy blithely breezes past the sign and descends the stairs, signaling to the viewer that for her, the nursery door is unlocked and the way out is ostensibly open. That is, at the outset of Us Addy's story begins where the journey of Campbell's hero ends.

Moments later standing on the sand and looking at the boardwalk, Addy sees a fun house which features a large sign reading 'Vision Quest' and an arrow pointing to the 
entrance with the imperative, 'Find Yourself.' Unlike Snow White who eats the poisoned apple and falls to the ground into a death-like sleep thus creating the conditions of her rescue by the Prince, Addy drops (makes fall) her apple on the sand and then crosses the beach towards the fun house. Once inside Addy's "quest for vision" is instantiated in an encounter with an animatronic owl, functioning as a freakish proxy for the animated owl who facilitates the erotic woodland encounter between Aurora and the Prince in Sleeping Beauty as well as the repeated owl imagery appearing as architectural elements in the house of the Seven Dwarves in Snow White. Venturing gingerly towards the interior of the fun house, Addy enters a simulacrum of the fairytale forest realm interlaced with warped floor to ceiling fun house mirrors. Like the apple and the owl, the mirrors inside the Vision Quest draw directly from the matrix of narrative elements constituting the primary couriers of signification in Snow White. The fairytale mirror is introduced in the first scene when the Evil Queen conjures its oracular power with the incantation, "Slave in the Magic Mirror. Come from the farthest space, through wind and darkness, I summon thee. Speak. Let me see thy face!" (00:02:30) at which point the Evil Queen reflected in the mirror dissolves to an image of a disembodied mask who asks, "What wouldst thou know, my Queen?" (00:02:49) It is important to note here that 1) that the disembodied mask which appears in the mirror functions as a specular avatar of the Evil Queen herself; 2) that the Evil Queen conjures the reflected phantasm representing her specular image using the vocative "slave;" and, 3) the disembodied mask constitutes an oracular archetype who is all-knowing and in a certain way all-powerful but is still subordinate to the will of a master. ${ }^{3}$ These observations suggest that the mirror in Snow White becomes the locus of a relay of meaning between the self and the specular image of the self which implies 1) that self-knowledge issues from an exteriorized source mediated by the mirror; and 2) that this knowledge is implicated in a hierarchical relation of power. In Us, as Addy presses deeper into the mirrored labyrinth of the Vision Quest, the reflected environment becomes ascendant. Addy walks towards a red neon Exit sign only to collide with a mirror in which the sign itself is but a reflection. Addy looks around to find the "real" referent for the reflected sign, but, instead, sees multiple Exit signs all functioning as reflections of each other without any way of determining the originary sign, if, indeed, there still is one. At this point Us suggests in the most beguiling way that for the subject who has completed the hero's journey according to Campbell's romantic modeling, the hero does not, in fact, find a permanent and irreversible self-actualizing beyond the threshold of the nursery, but, rather, finds herself entering another nursery, one in which the meaning of the Exit sign connotes its inverse, 'Enter,' requiring of the hero a subsequent and qualitatively new engagement with the journey, one in which the mirror as a structural metaphor and poetic instrument for the goal of 'finding yourself' becomes indispensable.

Seeking to orient herself, Addy walks backwards into a mirror where, behind her, the reflection of her back is already in place indicating that the phenomenology of ordinary reflection has been cleaved. Addy turns around and discovers not an image of herself in the mirror but rather, what we later understand is her Tethered self. As in Snow White the mirror constitutes the threshold of a primary dislocation between the self and the specular image of the self where the latter, though a "slave," asserts an agency 
independent of the self to varying consequences. In Snow White when the Evil Queen asks, "Magic Mirror on the wall, who is the fairest one of all," (00:02:52) the question which has no answer because there is ostensibly only one answer is rhetorical; the Evil Queen expects the Magic Mirror to name her as the fairest one of all since the Magic Mirror functions practically as a narcissistic representation of the Evil Queen herself. Instead, the "slave" responds, "a lovely maid I see...alas, she is more fair than thee" (00:03:04). It is precisely the disjunction between the Evil Queen's non-interrogative and the Magic Mirror's response which sets the narrative of Snow White in motion. That is, if the Magic Mirror had answered in a way that aligned with the Evil Queen's expectation - "You are the fairest one of all" (00:01:57) - the narrative of Snow White would not exist. Though $U s$ begins with a dislocation between the self and the specular image of the self at the threshold of a mirror which is structurally similar to what transpires in Snow White, the viewer eventually discovers that the dispassionate reality check issued by the Magic Mirror to the Evil Queen is radically escalated in Us to what can only be described as a full scale mutiny waged by the specular image of the self against the self. How this revolt as a narrative event figures essentially in a secondary elaboration of the hero's journey not the one undertaken by Campbell's universal man of self-achieved submission, but, rather, by Addy, a 10 year old African-American girl who encounters her 'untethered' reflection in the mirrored surface of the Vision Quest which instructs her to 'find [her] self' - is exactly the question that the current inquiry seeks to explore.

In order to fully understand the refracted role of the mirror as a cinematic sign in $U s$, this study posits as indispensable the heuristic of the mirror stage which Lacan adumbrated in his 1949 lecture The Mirror Stage as Formative of the I Function as Revealed in Psychoanalytic Experience. The mirror, illuminates Lacan, functions as an instrument of psychic mediation illustrated by a child who "playfully experiences the relationship between the movements made in the image and the reflected environment, and between this virtual complex and the reality it duplicates" (Lacan 74). It is important to understand here that Lacan describes two distinct apperceptions which are sourced fundamentally in a cognitive act of differentiation: the first distinguishes between the self and everything in the reflection that is not the self; and, the second distinguishes between the plenary reflection in the mirror ("this virtual complex") and the real environment reflected. The consecutive relay of perceptions in the order that Lacan describes them constitutes for the budding subject an aggregate moment of recognition in which his "I is precipitated in primordial form prior to being objectified in the dialectic of identification with the other, and before language restores to it, in the universal, its function as subject" (Lacan 76). In other words, the mirror becomes in Lacan's psychoanalytic framework not only the locus of a primary anchoring of the inchoate I which later serves as the scaffolding for the subject's interface with the social dialectic; the logistics of looking and reflection at the site of the mirror, in fact, plays a causal role in effecting and instantiating the preliminary I structure required for secondary identifications. At the start of his discussion of the mirror stage Lacan feels compelled to state that subjectivity does not arise from cogito short-hand for the Cartesian conception of "I think therefore, I am" which Freud himself vacated early in his work on dreams with his theorizing on the unconscious. Rather, the mirror becomes a critical referent in Lacan's thesis precisely because it is appropriately 
descriptive of the constitutive potential of an exteriorized mimicry which precipitates the recognition required in a gestalt, also known as Aha-Erlebnis, for the nascent $I$ to take hold. That is, becoming is not an effect of consciousness; rather, it is, in the first instance, actualized through imitation. Lacan goes on to describe how the mirror situates the $I$ "in a fictional direction that will forever remain irreducible for any single individual, or, rather, that will only asymptotically approach the subject's becoming no matter how successful the dialectical syntheses by which he must resolve, as $I$, his discordance with his own reality" (Lacan 76). So, further to identifying the mirror as an instrument which mediates a productive becoming through mimicry, that becoming, Lacan suggests, is ultimately an idealized fiction -the ideal $I$ - which the subject will never inhabit though he will expend the capital of his socially-determined reality trying to achieve it. What is critical to note, here, is that for Lacan, the fiction in the mirror which the I misapprehends as the self is not value neutral. His ruminations at this point become dark as he contemplates the futility of culture as an effective intervention for the subject's "organic inadequacy of his natural reality" (Lacan 77) and the "aggressiveness deriving therefrom" (Lacan 79). Though Lacan never uses the word "truth" in his discussion of the mirror stage, the model of the subject implied by Lacan's construct constitutes his attempt to describe a structure of the self which at the very least is consistent with his conception of the psychoanalytic framework he subscribes to. It's clear that Lacan believes that psychoanalysis provides the appropriate framework and palliative for the mental afflictions, neuroses and psychoses, suffered by individuals and communities and he asserts and affirms the active role of the analyst in any potential path to healing: "psychoanalysis can accompany the patient to the ecstatic limit of the 'Thou art that,' where the cipher of his moral destiny is revealed to him, but it is not in our sole power as practitioners to bring him to the point where the true journey begin" (Lacan 81). The ecstatic limit referred to by Lacan is nothing less than the threshold of the specular image. Like a guide the analyst facilitates the subject's approach to the limit demarcating the asymptotic vector which makes manifest his becoming; but, beyond that, the analysand who in his prior avatar as the hero journeyed towards the world (Umwelt) in order to selfactualize, must now embark on a secondary and esoteric iteration of the journey, one that ventures towards the mirror where he encounters his defining exteriority both obscuring and denuding the structuring emptiness of his becoming and being.

Consider for a moment that every protagonist of narrative is likely already a patient, an enterprising analysand whose motivation to journey is sourced in the dehiscence of the self inaugurated by the mirror. Us opens with a medium shot, not of a mirror, but of a television featuring an animated teaser for the local news. The broadcast ends and the television darkens just long enough for the viewer to see an image of Addy reflected on screen, seated on a couch with a stuffed toy bunny beside her and using scissors to cut from what appears to be a book of paper dolls. As stated above Lacan's first observation about the structuring function of the mirror identifies the relationship of the reflected subject to the reflected environment which he characterizes as the "lure of spatial identification" (Lacan 78) and "spatial capture" (Lacan, 77). It is interesting to note that the opening shot of Us does not reveal the 'real' side of the reflected image; that is, the camera never pivots to show the viewer the phenomenological real Addy sitting on the couch. Rather, tracking towards 
the television, we see Addy's image on screen visually displaced with an announcement for Hands Across America, a public event in which "six million people will tether themselves together to fight hunger in the United States" (00:02:17). Addy's "real" does not derive from the reality which presumably exists proximate to the boundaries of the television screen; rather, it's what plays on screen where the television as an iteration of the mirror offers a fascinating elaboration on the mechanics of the mirror stage. Though Lacan states that the primordial $I$ becomes the linchpin for the $I$ which comes to exist dialectically within the symbolic order, he does not exactly describe how this alignment takes place. He simply states that it does. I would argue that the shot of the television which opens $U s$ illustrates in a compelling way a possible engineering of the interlocution between the intra-subjective I represented by unseen "real" Addy and her reflection on the television screen and the inter-discursive $I$ produced by the visual palimpsest kinesthetically effected when Addy's reflection is vacated by the social and symbolic construct of the television broadcast. The Hands Across America ad features a graphic of linked human-body geometric cut-outs draped across a map of the United States. Considering that one of the connotations of $U s$ is undoubtedly "U.S.", it would follow that the benign joining of hands for the Hands Across America event undoubtedly signifies the chain-gangs of the pre-Civil War south for AfricanAmerican Addy, in any case. That Addy's reflection on the television screen dematerializes co-terminus with the Hands Across America broadcast suggests that her primordial $I$ captured by the television screen, lists towards the unachievable ideal $I$ represented by the images of racial harmony featured in the Hands Across America broadcast; the rhetorical logic of the ad presumes to offer Addy an opportunity for her to instantiate her ideal self, namely, as a black woman squared with the priorities of social equivalencies and of social justice. However, and this is what I believe Peel seeks to express in deploying the Hands Across America event as a macro-signifier in Us, for Addy, a girl who will become a woman socially constructed as black in the U.S., the semantic ramifications of 'tethering' must also necessarily include experiences of bondage and entrapment which only the black analysand as the inheritor of an iteration of the symbolic order torqued towards African-American racial history can understand. For, as Lacan states subtending all "relations involving aid of the most good-Samaritan variety" (Lacan 79) of which the rhetoric of racial harmony in the Hands Across America ad could be considered an instance is a fundamental aggression issuing from the structuring tension between the "narcissistic libido" (Lacan 79) representing the drive towards the ideal and the "alienating I function" (Lacan 79) which guarantees its failure. Is it any surprise, then, that the voiceover for the Hands Across America ad states that it is a "a 4000-mile-long chain of Good Samaritans standing hand in hand...from sea to shining sea?" (00:02:02). Lacan's thesis along with Peele's intent are unequivocal: subjectivity itself is structured in a relationship of bondage, one in which the subject is abjectly tethered to an avatar of the self -the ideal $I$ - that is always already out of reach. If, indeed, there is an exit from the binding entrapment engineered into the capture effected by the mirror, only Addy, black and having completed the hero-task according to Campbell, is in a position to undertake the journey because only a subject whose identity within the social dialectic is informed by the bondage of American racial history has the requisite inter-discursive knowledge to interrogate the same in the relays of meaning informing the intra-subjective $I$. 
Addy, it turns out, is herself the protagonist of a fairytale, not her own, but one told by Red, Addy's Tethered seen earlier in the film as a girl and now like Addy, a grown woman. Red is a doppelganger, a narrative modifier and an auxiliary subject, who has lived a parallel life in the penumbra of an underground world as Addy's "shadow" and for this reason feels alienated and angry and is possessed of a demonic aggression. That said, as Red tells her story, it's difficult not to empathize; she states, "when the girl (meaning Addy) ate, her food was given to her warm and tasty. But, when the shadow was hungry, she had to eat rabbit raw and bloody" (00:45:29). It's clear that in telling Addy her/their story Red is on a mission whose scope can be ascertained by its content. As previously noted, Lacan's conception of the mirror's structuring function is not value neutral. He states, "this moment at which the mirror stage comes to an end inaugurates, through identification with the imago of one's semblable and the drama of primordial jealousy, the dialectic that will henceforth link the I to socially elaborated institutions" (Lacan 79). Sitting in the living room with Jason, Zora and Gabe, Addy and her family are each confronted by the material presence of their respective doppelganger or, their "semblable(s)" which Jason astutely observes when he says, "it's us" (00:44:39). Imago in Lacan's paradigm designates the linchpin mentioned earlier - a structural feature of subjectivity facilitating the "palimpsesting" of the intra-subjective $I$ with the symbolic order. As Red tells her story to Addy her description of the disparities between her life and Addy's escalates: "on Christmas the girl received wonderful toys, soft and cushy. But, the shadow's toys were so sharp and cold, they'd slice through her fingers when she tried to play with them" $(00: 45: 47)$. It's critical to understand at this point that though Lacan states that the form of the ideal $I$ derives from an exteriority, namely, the reflection in the mirror, I would argue that the status of the exteriorized image is never more or less exterior to the self than the looking subject, or non-ideal $\mathrm{I}$, who in a pure application of Lacan's heuristic must also be considered as constructive of the imago. This observation manifests the difficulty in speaking about the mechanics of the mirror stage without resorting to the dialectic of 'real' and 'reflected' which the phenomenology of a mirror necessarily implies. This challenge noted and notwithstanding, the elaboration of Lacan's framework offered above makes clear that the functioning of the mirror instantiates both the non-ideal $I$ and the ideal $I$ simultaneously as imagos, each required and requiring the other for the inter-constitutive structure of the aggregated imago or primordial $I$. This reformulation is important in so far as Lacan's description of the mirror stage renders the ideal $I$ inert or fixed characterizing it as a "mental permanence" (Lacan 76) and having a "rigid structure" (Lacan 78). An understanding of the ideal $I$ which conceives of it as having the same kind of agency and libidinal circuitry as the non-ideal $I$ enables an apprehension of the mirror function which sets the stage for an internecine conflict located at its threshold. The aggression characteristic of the non-ideal I according to Lacan also applies as an attribute to the ideal $I$. The non-ideal $I$ directs aggression sourced in what Lacan refers to as a primordial jealousy towards the ideal $I$ which is perceived as an unobtainable exteriority and thus a rival; the exteriority also capable of agency as argued above seeks simultaneously to annihilate and displace the non-ideal I precisely because the non-ideal $I$ seeks to annihilate it. Mobilizing this reconceptualization of the mirror stage, Red's intent in surfacing becomes clear. In response to Addy's question, 
"What do you want?" (00:56:03) Red's response resonates: "What do we want? We want to take our time. We've been waiting for this day for so long. I call it 'The Untethering"' (00:56:26). Red grabs Addy by the hair and pushes her head into a glass table. The table's reflective surface, functioning as a proxy for the mirror much like the television already discussed, represents the specular threshold where the structure binding the non-ideal $I$ and the ideal $I$ manifests itself. It is interesting to note that at this point in the narrative Red is posited as the ideal I who, as it turns out, presents as a monstrous avatar of Addy with only two chambers in her heart represented by the handles of the gold scissors she wields. That is, she is not ideal in the least if, indeed, less, or fewer chambers, is less ideal than more. As Red transgresses the boundary established by the mirror fueled by aggression and specifically her jealousy towards Addy, the table cracks under Addy's head offering a visual manifestation of the intra-subjective rupture. The ritual of annihilation planned by Red makes sense: in order for Red to usurp Addy's position on the other side of the mirror, which is, as suggested in Red's narrative, the right side of the mirror, or, at least, the better side of the mirror, she and her tethered compatriots must vacate the space occupied by their surface counterparts through murder.

What recourse does the non-ideal $I$ have when the ideal $I$ goes beserk? One option is to run which is what Zora does. Another is to momentarily and haplessly succumb which is what Gabe does. And, another is to play a game of mirror which is what Jason and Pluto do in the closet. The scene stages in a compelling way Lacan's articulation of the mise-enscene of primary identification which he describes as the

"striking spectacle of a nursling in front of a mirror who has not yet mastered walking, or even standing, but who - though held tightly by some prop, human or artificial (what we in France call a trotte-bébé [a sort of walker]) - overcomes, in a flutter of jubilant activity, the constraints of his prop in order to adopt a slightly leaning-forward position and take in an instantaneous view of the image in order to fix it in his mind" (Lacan, 76).

Sitting cross-legged on the carpet inside the closet and facing each other Pluto lights a match illuminating himself and Jason. The flame powers up the circuitry of Jason and Pluto's mirroring by establishing the threshold of their reflective dynamic. Pluto who wears a white mask on his face lowers the monster mask onto Jason's, an action which advances their reflective symmetry. Pluto then gestures animatedly for Jason to ignite a trick lighter anchored to Jason's index finger which if illuminated would complete Jason and Pluto's symmetrical dynamic. Unable to get the lighter to work Jason gives up after a few tries. Instead, he raises his hand, which Pluto mirrors and then lifts his mask prompting Pluto to do the same. Jason is horrified to discover that Pluto's face is covered with scar tissue. With the rules of the mirror game now established Jason lowers his mask spurring Pluto to follow. Pluto focuses once again on the lighter and gestures for Jason to light it. Though Jason gets the lighter to spark, he uses the moment which is unexpected to escape the closet and lock Pluto inside. It is important to note that at no point during the scene does Pluto manage to get Jason to engage in a reciprocal gesture of mimicry in which Jason imitates him. The implication for the intra-subjective relationship at the threshold of the 
mirror is that 1) agency which is most easily conceived of as a deployment of libidinal drive can only exist in any given moment on one side of the mirror; and 2) that the $I$ who is in possession of agency by virtue of harnessing libido is ascendant. The upshot for Jason and Pluto's game of mirror is that Jason functions as a structural conduit for Pluto's becoming and not the other way around. The possibility of joint agency or shared power at this point in the narrative seems remote since in the living room Red has already expressed her intent to kill Addy without the possibility of negotiation. This is made evident when Gabe says to Red: "Excuse me. Excuse me. What do you want? You could have my wallet. You could have the car. You could have the boat for all I care (00:47:33). Zora clues Gabe in: "Nobody wants the boat, Dad." (00:47:56) No, nobody does, for how does money, or a car or a boat constitute an adequate replacement for cogito -the unique, luminous and intermittent potential of being no matter its status as a fiction. Getting the trick lighter to produce a flame would have instantiated Pluto as that subject effectively relegating Jason to the status of a reflection. Jason tricks Pluto, however, and instead ends up untethering himself engineering a reversal which becomes critical to the narrative action of $U s$ in the second half of the film, namely, that "Untethering" can go both ways. Lacan's advice for the analysand who has advanced to the secondary elaboration of the hero's journey because she has awakened, as Addy has, to the fundamental aggression characteristic of the I formation, is to start therapy; for, as he states "psychoanalysis alone recognizes the knot of imaginary servitude that love must always untie anew or sever" (Lacan 80) and, it is only within the framework of psychoanalysis, presumably, that the subject can leverage the "balance arm of the psychoanalytic scales" (Lacan 80 ) in order to, if not shed the violence of the intra-subjective dynamic, then, at the very least, direct its vectors to amortize the aggression subtending emotional and mental contagion. Barring that, now that the Untethered have surfaced in Us, it's kill or be killed which as a binary informs such narrative genres as zombie and horror all of which, I would argue, are structured tangentially or directly around revenge. Red's rage and her concomitant desire to murder Addy and displace her in order to take her place on the surface issues from an existential negation, or, within the psychoanalytic framework, a psychic negation which is undergirded by lack ${ }^{5}$. Red expresses exactly this to Addy when she itemizes everything that Red didn't have and Addy did. Cardinal among these "lacks" is choice, free will which is illustrated when Red states that she was forced to partner with Abraham because Abraham is tethered to Gabe; Red says, "The girl met a handsome prince and fell in love, but the shadow, at that same time, met Abraham. It didn't matter if she loved him or not. He was tethered to the girl's prince, after all" (00:46:06). Prior to Red's articulation of lack - both in its material form (sharp, cold toys) and immaterial form (the ability to choose a partner) - in her speech to Addy, lack as a signifier of absence is also expressed within a socially discursive context when Gabe states in response to losing power in the house and the lights going out, "See, this is why Josh has a backup generator" (00:36:36). Josh Tyler, his wife, Kitty and their kids, Lindsey and Becca are the white family in Us; we are introduced to them when Addy, Gabe, Zora and Jason go to the beach which is the selfsame location of Addy's encounter with her childhood doppelganger. Just as the Tethered function collectively as underground doppelgangers for Addy and her family, I would argue that Peele's intent in Us at this point in the film is to suggest that Addy and her black 
family function as "underground" counterparts to the Tylers qualified by what they don't have, what they lack, namely a backup generator, in relation to their white counterparts. The transitivity informing the hierarchy structuring the relationship of the three families can be understood in the following way: Red and her family lack in relation to Addy and her family; as Addy and her family lack in relation to Josh and his family. Power in the scene where the lights go out just before the Tethered arrive not only denotes electrical power; it also gestures to forms of discursive purchase within the social domain which includes privilege issuing from class and race. To lose power and to be without a backup generator for Addy, Gabe, Zora and Jason is to lack as a black family discursively what a white family has access to in case the lights go out, namely, white power and privilege. The transitive structure which relays the mechanics of identification from the intrasubjective to the inter-discursive is also illustrated when the power outage in the house is understood structurally as an antecedent to Jason's inability to get the trick lighter to work in the closet later in the film. Like Jason, Gabe is at the threshold of an encounter with his tethered counterpart, Abraham, who seeks to usurp his agency through murder. Whereas Jason who can be argued is pre-social uses his failure to get the lighter to ignite as a means of escape from Pluto, the power failure in the house and the absence of a backup generator actually creates the conditions for the Tethered to make their advance against Addy and her family. ${ }^{6}$ It's interesting to note that though at no point in $U s$ is there any manifest evidence of racial tension between Addy's family and Josh's, the absence of racially motivated hostility does not mean that it does not exist. Like Lacan, I would argue that Peele's vision of the appearance of racial harmony is informed by the psychoanalytic model of the subject per Lacan in which the aggression informing the intra-subjective I formation arising from lack maps onto the socially discursive structures specifically shaping the narrative of race in $U s$.

Us transits its focus from Addy and her black family to Josh and his white family after Addy, Gabe, Zora and Jason escape their tethered counterparts on the boat Gabe bought prior to the start of the film. A close up of a rocks glass sitting on a table next to a sleeping Josh initiates the move to the Tyler's home. The lights dim momentarily only to return signaling to the viewer that Josh's backup generator has kicked in. Josh wakes up, grabs a drink and takes a sip. Kitty appears on the balcony above him and says that she heard something outside and wants Josh to check it out. He gets up reluctantly and looks out the window. Feigning apperception of an intruder, Josh ultimately drops the pretense by saying, "Oh, shit! Oh my god, it's O.J. It's O.J. Simpson" (01:05:33) who in the American cultural imagination of the last 25 years represents the quintessential black monster who married a white woman, and if that wasn't enough, murdered her and got away with it. Unlike the Tethered who function as "a/socialized" doppelgangers for Addy and her family, meaning that they are not qualified in $U s$ by any socially discursive modifiers, the Tethered of the white family who appear soon after Josh's racially motivated joke, though white, feel black. Kitty is stabbed in the neck by her doppelganger; gurgling blood onto the carpet she crawls across the room to a now dead Josh. When Kitty tells the smart speaker, Ophelia, to call the police, Ophelia plays "Fuck the Police" by NWA, a black anthem condemning the police for their brutality against the black community and specifically black men; but also, it constitutes an affirmation of violence motivated by rage as a valid response to police 
brutality by the black men who are targeted: "It's gonna be a bloodbath of cops dying in LA" (01:09:10) -a bloodbath, indeed, one, I would argue, is sourced in the aggression of the intra-subjective relationship where the transitivity described above posits the black subject as the ideal repository for the non-ideal $I$ of the of the white $I$ formation. While the white subject aligns himself with the ideal $I$, the form and value of his non-ideal I is informed by the monstrous contours and prejudiced listings of the symbolic order. This process of dialectical identification, also known as "othering," simultaneously reinforces racial stereotypes within the socio-linguistic matrix which the white subject banks in order to ensure future depositories for the inter-discursive projection required by the I formation in order to manage his intra-subjective aggression. Needless to say the police never show up to rescue Kitty (presumably they are being murdered by their own Tethered) but Addy, Zora, Gabe and Jason do. Addy understands immediately that when Josh answers the door the man standing before her is, in fact, Josh's Tethered and whacks him in the head with a fireplace iron. Moments later Gabe sends the kids running away from the new cycle of narrative mayhem. He himself attempts to create a diversion leading Josh's Tethered away from them whom he refers to as "Bad Josh" (01:09:01), or, within the psychoanalytic framework, non-ideal Josh, the racist and politically-correct white pretender. Watching Addy, Zora and Jason kill Tethered Kitty and her girls is interesting in so far that the value of their labor signifies in a way that is different than when they are killing the black Tethered. I would suggest that when Jason finally manages to bludgeon Kitty, for example, he is, in fact, murdering the white non-ideal $I$ who would seek to project her devalued status, her lack, onto Addy as a black woman. It is interesting to note here that Tethered Kitty suggests to the viewer that she also exists in a relationship of otherness to an unseen subject who is implied when Tethered Kitty puts on lipstick and admires herself in the mirror. The lush romantic orchestral soundtrack -in stark contrast to "Fuck the Police"is redolent of Hollywood in the 50s, a period when female movie stars defined the ideals of white femininity of two generations. Tethered Kitty, after admiring herself in a mirror starts to cry and then laugh, evincing an appropriately psychotic response to the pressure of an illusory an obtainable exteriority defined by the symbolic order. That said, would ideal Kitty or ideal Josh, now dead, ever present their "underground" racism to Addy and her family? Is it conceivable that Josh would make the O.J. Simpson joke whose correct understanding is as an act of racial aggression in the presence of Gabe thus rupturing the illusion of racial harmony?

Peele's uncommon simulacrum of black empowerment in Josh's house ends and Addy and her family end up in the living room watching as the Tethered take over the world. Addy wants to leave and keep moving while Gabe who cites the backup generator as desirable wants to stay. Addy is adamant, however: "They think like us. They won't stop until they kill us or we kill them" (01:19:38) which makes one wonder if in subscribing to a model of the subject whose interstices belie a structuring lack that is the cause of an unabated-able aggression, is there, indeed, any hope for the subject? For respite, or, more remotely, for a negotiated peace. According to Us there isn't; after the cleaving of the structure of the I formation, it seems that the only outcome for the ideal $I$ and the non-ideal $I$ alike in their rivalry, in their pursuit to be ascendant, is the survival of the one which is contingent upon annihilation of the other. With Gabe and Zora's Tethered dead, it comes to Jason to 
kill his own. Driving the next day in the Tyler's car Addy makes a turn where she, Gabe, Zora and Jason discover their own car parked at a right angle on fire with Pluto standing in front. Addy stops the car and gets out holding the fire iron with the intent to kill Pluto. When she is close enough to hit him, however, she hesitates, forgetting in a moment of misrecognition brought on by the fact that Pluto is gesturing as if to light the trick lighter, that Pluto's aim is to kill her. Jason figures out that Pluto's plan is to blow up the car. He gets out along with Zora and Gabe and does what Addy cannot. As mentioned above Jason is not so far from the instantiating moment of recognition in the mirror to have completely forgotten how it works. Extrapolating from his encounter with Pluto in the closet, Jason deploys the mise-en-scene of the mirror stage and the mimicry which it compels to initiate Pluto's retreat from Addy by walking backwards himself. The distancing induces Pluto to reverse into the conflagration consuming the car behind him. It is a beautiful, heartwrenching scene which perfectly illustrates Lacan's reference to transitivism ${ }^{7}$ in children, a behavioral model which provides the phenomenological basis of his conception of the mirror stage. Returning now to the final scene in Us after Addy has murdered Red and rescued Jason, her recollection of what happened in the Vision Quest which is staged as a flashback becomes clear: young Addy backs into the mirror where, as noted above, her reflected back is already in place indicating that Addy's ideal $I$ has at that moment assumed agency of Addy's I formation. The ideal I strangles the non-ideal I rendering her unconscious and drags her underground. The ideal $I$ surfaces and lives as an imposter of the non-ideal I who herself spends her life in the sewers and comes to be known as Red. Red emerges at the appointed time with the aim of reclaiming her rightful place on the surface. Addy, however, refuses to cede her position and finally kills Red ensuring her dominion over the I formation. I would suggest that the secondary and esoteric elaboration of the hero's journey sees the ideal $I$ advance towards her goal of securing her dominion over the subject. In Us Addy -the ideal I- is the true hero and protagonist of the esoteric iteration of the journey though we do not directly witness the beginning of her journey, we only see its reflection in the movements of the "real" Addy, the non-ideal $I$, at the opening of the film. The question Us poses is this: if the ideal I's act of self-liberation necessarily requires the bondage of the non-ideal $I$, can that action be considered liberative? Is it possible given Lacan's model of the subject discussed above that the liberation of the self must necessarily involve its bondage as well? Do we have place within our moral framework -the one that enjoins the tethering of hands across America-as a good Samaritan act- to allow for a form of self-annihilation which constitutes a pathway to self-actualization? To accept this as an existential truth and live with it? Advancing towards the climax of Us Addy goes after Red who has taken Jason underground. Before they fight to the death Red has a moment in which she very nearly thanks Addy for her aggression against her as a child at the threshold of the mirror: "And, to think if it weren't for you I never would have danced at all" (01:41:30) - possibly suggesting that only the liberation of the ideal $I$ which necessarily implies the bondage of the non-ideal I results in the creation of beauty. At the end of the esoteric journey which requires Addy to kill Red, Addy remembers who she is and what she did - she "finds herself." Addy keeps event of the swap at the mirror and the manner in which she executed it a secret. Us concludes with Addy driving an ambulance taking her family to Mexico which is presumably beyond the perimeter the Tethered's Hands Across 
America event. Addy looks at Jason sitting in the passenger's seat. It's clear that he knows about her, that she is an imposter from the sewers masquerading as the non-ideal $I$ on the surface. Staring at Addy Jason lowers the monster mask onto his face. In doing so he assumes the representation of the non-ideal $I$ to mirror in order to mirror hers.

\section{Notes}

1. See Kapila for a discussion of The Hero's Journey and fairytale structure.

2. Addy's mother tells her to stay put while she goes to the bathroom. Addy, instead, walks away. Like Campbell, Vladimir Propp identifies Addy's departure as a fairytale function called "The Hero Leaves Home." Addy's mother's command to her is a positive version of Propp's "interdiction." This is known as in Propp's framework as "An interdiction is addressed to the hero. Addy's departure can then also be qualified by "The Interdiction is Violated" function (Propp 26-39).

3. Other examples of the oracular archetype are the "genie in the bottle" and the blind Tiresias from Oedipus Rex.

4. Tonally, Red's complaint verges on farce which in the context of the terror brought about by the appearance of Red and her family at Addy and Gabe's summer home is interesting.

5. I am using "lack" here in relation to desire as it has been broadly defined over the arc of the Lacanian oeuvre where material lack connotes in the context of $U s$ psychic lack produced by the disjunction of the I formation.

6. Though Us presents a rich and compelling opportunity for a discussion of black masculinity, it is not within the scope of this essay to undertake that study.

7. Lacan 79 .

\section{Bibliography}

Campbell, Joseph (2008). The Hero with a Thousand Faces. New World Library.

Lacan, Jacques (2006). Écrits. W. W. Norton \& Company, Inc.

Kapila, Gitanjali. "Stuck in a Labyrinth (or a Tower) with the Minotaur and trying to get out: Princess Aurora and Imperator Furiosa as the heroes of the Multimyth." Cuadernos del Centro de Estudios en Diseño y Comunicación No 91, May 2019. https:// fido.palermo.edu/servicios_dyc/publicacionesdc/cuadernos/detalle_articulo.php?id_ articulo $=16341 \&$ id_libro $=786$

Propp, Vladimir (1968). Morphology of the Folktale. University of Texas Press.

Us. Directed by Jordan Peele, Universal Pictures, 2019.

Snow White. Directed by David Hand, Walt Disney, 1937. 
La heroína negra en el espejo: Cruzando el límite de la imagen especular, el esotérico periplo y el encuentro con el aniquilador I en la obra: Nosotros de Jordan Peele

Resumen: Utilizando el marco conceptual del estadío del espejo establecido por Lacan para describir el anclaje inicial del tema, este artículo busca interrogar al espejo como el lugar de una elaboración secundaria del viaje del héroe que sigue su articulación tradicional esbozada por Joseph Campbell en El Héroe de las mil caras. Si el objetivo del héroe clásico, como sugiere Campbell, es salir de la guardería que representa el confinamiento del sujeto en la triangulación edípica, este estudio plantea que la liberación exitosa del héroe de la guardería simplemente lo ve entrar a otra guardería donde está el mundo del héroe, concebido como una serie de guarderías infinitamente anidados sin salida. El espejo y el umbral especular que éste instancia se convierten en el punto de partida ejemplar para la elaboración secundaria del viaje para el cual la heroína negra es la aventurera ideal. No es de extrañar que Jordan Peele's Us esté repleto de espejos que funcionan como significantes cinematográficos para los portales que efectúan el desplazamiento del sujeto no hacia un mundo exterior de padres agresivos y madres ideales imposibles de obtener; sino, más bien en un encuentro cercano con uno mismo, un encuentro precipitado por el espejo donde el objetivo del viaje, el que solo puede ser revelado por la heroína negra, es la aprehensión de la estructuración "clave de [su] destino moral" y el funcionamiento insondable de su verdadera salida.

Palabras clave: Us - Blancanieves - Peele - Lacan - Campbell - Freud - Función del Yo espejo - psicoanálisis - héroe - viaje del héroe - raza.

\section{A heroína negra no espelho: atravessando os limites da imagem no espelho, a esotérica Viagem e encontro com o aniquilador I na obra: Nosotros, de Jordan Peele}

Resumo: Usando a estrutura conceitual do estágio do espelho estabelecida por Lacan para descrever a ancoragem inicial do tema, este artigo procura interrogar o espelho como o local de uma elaboração secundária da jornada do herói que segue sua articulação tradicional delineada por Joseph Campbell em O Herói do mil rostos. Se o objetivo do herói clássico, como sugere Campbell, é deixar o berçário que representa o confinamento do sujeito na triangulação edipiana, este estudo propõe que a liberação bem-sucedida do herói do berçário o veja entrar em outro berçário onde está o mundo do herói, concebido como uma série de berçarios infinitamente aninhados sem saída. O espelho e o limiar especular que o espelho genera se tornan o ponto de partida exemplar para a elaboração secundária da jornada para a qual a heroína negra é a aventureira ideal. Não é de admirar que Us de Jordan Peele esteja repleto de espelhos que funcionam como significantes cinematográficos para portais que afetam o deslocamento do sujeito, não para um mundo exterior de pais agressivos e mães ideais impossíveis de obter; mas antes, em um encontro íntimo consigo mesmo, um encontro precipitado pelo espelho, onde o objetivo da viagem, que só pode ser revelado pela heroína negra, é a apreensão da estruturaçao "chave do [seu] destino moral" e o desempenho insondável de sua verdadeira saída. 
Palavras chave: Us - Branca de Neve - Peele - Lacan - Campbell - Freud - Função do Eu - espelho - psicanálise - herói - jornada do herói - raça.

[Las traducciones de los abstracts fueron supervisadas por el autor de cada artículo] 